\title{
Response to Lactation Induction Differs by Season of Year and Breed of Dairy Ewes
}

\author{
B. Ramírez Andrade, ${ }^{*} \dagger$ A. A. K. Salama, ${ }^{\star} \ddagger$ G. Caja, ${ }^{* 1}$ V. Castillo, ${ }^{*}$ E. Albanell,, ${ }^{*}$ and X. Such* \\ ${ }^{*}$ Grup de Recerca en Remugants, Departament de Ciència Animal i dels Aliments, Universitat Autònoma de Barcelona (UAB), \\ 08193 Bellaterra, Spain \\ †Facultad de Agronomía, Universidad Autònoma de San Luis Potosí, 78321 San Luis Potosí, México \\ $\ddagger$ Sheep and Goat Research Department, Animal Production Research Institute, 4 Nadi El-Said St., 12311 Dokki, Giza, Egypt
}

\begin{abstract}
Lactation artificially induced (ART) by steroid hormones and natural lactation (NAT) after lambing were compared in 2 dairy sheep breeds (Manchega and Lacaune) in 2 experiments conducted during winter and spring. In experiment 1, ART ewes (14 Manchega and 9 Lacaune) were induced into lactation in winter by the standard protocol, which consisted of s.c. injections of estradiol and progesterone administered in 2 portions daily from $d 1$ to 7 . Hydrocortisone acetate was injected s.c. daily on d 18 to 20 . Milking was initiated on d 21 and continued for 13 wk. A similar group of NAT ewes was selected for the contemporary comparison of NAT vs. ART lactation. All Lacaune ewes, but only 3 of the 14 Manchega ewes (21\%), were successfully induced into lactation. Despite the successful induction of lactation in Lacaune ewes, milk yield was much lower than that obtained in NAT lactation $(1.23 \pm 0.14$ vs. $2.51 \pm 0.15 \mathrm{~L} /$ d). Milk composition from wk 5 to 13 did not differ between groups, except for whey protein, which was greater in ART than in NAT ewes (1.47 vs. $1.25 \%)$. In experiment 2, 19 Manchega ewes were divided into 2 groups and induced into lactation in spring by using the standard induction protocol, similar to that used in experiment 1 (control, $n=9$ ), or the standard protocol modified with bovine somatotropin (bST, $250 \mathrm{mg} / \mathrm{ewe}$ on $\mathrm{d} 11 ; \mathrm{n}=10$ ). Manchega ewes had an improved response to the standard protocol of lactation induction in spring compared with winter. Milk yield in bST-treated Manchega ewes was $98 \%$ greater than that in control ewes (402 \pm 85 vs. $203 \pm 86 \mathrm{~mL} / \mathrm{d}$ ). The use of bST during mammogenesis did not affect milk composition. In conclusion, marked differences between Manchega and Lacaune dairy ewes were observed in their response to lactation induction when using the standard protocol during different photoperiod conditions. The Manchega
\end{abstract}

Received September 13, 2007.

Accepted February 14, 2008.

${ }^{1}$ Corresponding author: gerardo.caja@uab.es ewes were unable to establish lactation in winter but were able to do so in spring. The response to lactation induction in dairy ewes seems to be related to their endogenous levels of prolactin and growth hormone, the use of which should be explored more deeply in future research.

Key words: lactation induction, somatotropin, milk composition, dairy ewes

\section{INTRODUCTION}

Hormonal induction of lactation in ruminants contributes to the understanding of lactation physiology and, potentially, will be useful in reducing unproductive periods in intensive dairy management systems. Numerous attempts to induce lactation with ovarian steroids (Cowie et al., 1965; Smith and Schanbacher, 1973; Salama et al., 2007) have resulted in variable success rates (58 to $80 \%$ ) and milk yields (50 to $106 \%$ of natural lactation). Moreover, the use of large doses of estrogen has led to side effects such as the undesirable exhibition of estrus behavior over prolonged periods (Smith and Schanbacher, 1973) and has affected fertility negatively (Salama et al., 2007).

To improve the response of cows, ewes, and goats to the induction treatment, researchers have added placental lactogen (Byatt et al., 1997; Kann et al., 1999), somatotropin (Kann, 1997; Kann et al., 1999; Kensinger et al., 2006), prostaglandins (Lukas et al., 2003), reserpine (Collier et al., 1977; Kensinger et al., 1979; Salama et al., 2007), and thyroid hormones (Hart and Morant, 1980; Head et al., 1980). The effects reported by using reserpine, a prolactin releaser, suggest that differences in the response to lactation induction occur because of season of the year and the photoperiod sensitivity of the animals.

Most studies of lactation induction in sheep have been conducted with Prealpes du Sud ewes (Kann, 1997; Kann et al., 1999; Head et al., 1980), which is a dual-purpose local French breed and not a true dairy sheep, or with local dairy ewes of a nonspecified breed (Alifakiotis et 
al., 1980). Kann (1997) and Kann et al. (1999) concluded that the inclusion of growth hormone in the induction protocol is necessary to improve milk yield in ewes.

To our knowledge, no studies have been conducted to evaluate the results of induced lactation in specified dairy sheep breeds in which a greater success rate and milk yield should be expected. Moreover, little is known about differences in milk composition in dairy ewes that have been artificially or naturally induced to lactate.

The aim of this study was to compare the lactational response to hormonal treatment of lactation induction in ewes of 2 dairy breeds that differ in their productive potential. Induced lactation by the standard protocol proposed by Smith and Schanbacher (1973) was compared with natural lactation during winter (experiment 1), and this standard protocol was compared with a modified protocol with bST in spring (experiment 2).

\section{MATERIALS AND METHODS}

The experimental procedures and animal care conditions were approved by the Ethics Committee of Animal and Human Experimentation of the Universitat Autonoma de Barcelona (reference CEEAH 606/2006).

\section{Animals and Treatments}

Experiment 1. A total of 46 ewes from 2 dairy breeds that differed in milk production potential (Manchega, medium yield, $\mathrm{n}=28$; Lacaune, high yield, $\mathrm{n}=18$ ) were used to study the response to lactation induction by a standard protocol based on the use of steroid hormones. During winter, 23 dairy ewes were artificially (ART) induced into lactation (Manchega, $\mathrm{n}=14 ; 9$ nulliparous and 5 multiparous; and Lacaune, $\mathrm{n}=9 ; 4$ nulliparous and 5 multiparous) and compared with 23 dairy ewes naturally (NAT) lambed (Manchega, $\mathrm{n}=14 ; 9$ primiparous and 5 multiparous; and Lacaune, $\mathrm{n}=9 ; 5$ primiparous and 4 multiparous) at the experimental farm of the S1GCE de la Universitat Autonoma de Barcelona in Bellaterra, Spain $\left(41^{\circ} 30^{\prime} \mathrm{N}, 2^{\circ} 5^{\prime} \mathrm{E}\right)$.

To eliminate the possible effect of the reproductive state of the ewes on the response to hormones used to induce lactation, ART ewes were estrus synchronized (starting January 23) for $12 \mathrm{~d}$ by insertion of a polyurethane vaginal sponge that contained $40 \mathrm{mg}$ of fluorogestone acetate (Chronolone, Intervet, Salamanca, Spain), and 400 IU of pregnant mare serum gonadotropin (Foligon, Intervet) i.m. was injected at the time of sponge withdrawal. Five days after sponge withdrawal, ewes were induced into lactation by using the standard protocol of Smith and Schanbacher (1973) based on daily s.c. injections of estradiol- $17 \beta(0.5 \mathrm{mg} / \mathrm{kg}$ of $\mathrm{BW})$ and progesterone $(1.25 \mathrm{mg} / \mathrm{kg}$ of $\mathrm{BW})$ in 2 portions at 0800 and
$1800 \mathrm{~h}$ from $\mathrm{d} 1$ to 7 . Lactation was triggered by hydrocortisone acetate $(50 \mathrm{mg} / \mathrm{d})$ injected s.c. daily for $3 \mathrm{~d}(\mathrm{~d} 18$ to 20). Milking was initiated on d 21 (February 28) and was continued for 13 wk.

The NAT groups of ewes naturally lambed from each breed for use in the contemporary comparison of NAT vs. ART lactation were selected from the dairy flock of the S1GCE (Servei de Granges i Camps Experimentals) according to lambing dates. The NAT ewes were mated after synchronization by ram effect, lambed on February 22 ( $\pm 5 \mathrm{~d}$ ), and suckled their lambs for $4 \mathrm{wk}$. Milking was initiated after weaning the lambs at $27 \mathrm{~d}$ of age (March $21)$ and was continued for $154 \mathrm{~d}$ ( $22 \mathrm{wk})$. Animals and treatments used in experiment 1 are summarized in Table 1.

Experiment 2. Most of the ART Manchega ewes used in experiment 1 failed to establish lactation (milk yield $<0.2 \mathrm{~L} / \mathrm{d}$ ). All of them were dried off for $44 \pm 1 \mathrm{~d}$ and reused in a second induction experiment in which a modified protocol with bST was used. To permit steroids to clear the body, a period of $68 \mathrm{~d}$ was allowed between the last steroid injection in experiment 1 and the first steroid injection in experiment 2. Four new nulliparous and 1 multiparous nonpregnant Manchega ewes were included in the experiment.

Manchega ewes $(n=19)$ were divided into 2 groups in early spring, estrus-synchronized via vaginal sponges (starting April 10), and induced into lactation by the same standard protocol used in experiment 1 or by the same protocol in which bST was included. Ewes of the standard protocol were used as a control (control: 6 nulliparous and 3 multiparous). Ewes of the modified protocol were injected s.c. with a single dose of prolongedrelease bST (Lactotropina, $250 \mathrm{mg} / \mathrm{ewe}$; Elanco Animal Health Mexico, Guadalajara, Jalisco, México) on d 11 (bST: 7 nulliparous and 3 multiparous). The animals and treatments used in experiment 2 are also summarized in Table 1.

\section{Hormones}

Steroid hormones for lactation induction were supplied by Sigma-Aldrich (Sigma-Aldrich Química, Barcelona, Spain). Estradiol-17 $\beta$, progesterone, and hydrocortisone acetate were dissolved in dimethyl sulfoxide (USP grade DMSO, Gaylord Chemical Co., Slidell, LA) to give concentrations of $1,003,44$, and $245 \mathrm{~g} / \mathrm{L}$, respectively. Solutions were protected from light and stored at room temperature. Insulin syringes $(1 \mathrm{~mL}, \mathrm{BD}$ Medical-Diabetes Care, San Agustín del Guadalix, Madrid, Spain) were used for estradiol and hydrocortisone acetate injections.

The bST (Lactotropina) was supplied by Elanco Animal Health Mexico as syringes of $500 \mathrm{mg}$ of zinc bovine somatotropin and stored at $4^{\circ} \mathrm{C}$ until their use. Each 
Table 1. Breed and parity of the ewes used per treatment in the lactation induction experiments

\begin{tabular}{|c|c|c|c|c|c|}
\hline \multirow[b]{2}{*}{ Breed } & \multirow[b]{2}{*}{ Parity } & \multicolumn{2}{|c|}{ Experiment 1} & \multicolumn{2}{|c|}{ Experiment 2} \\
\hline & & Natural & Artificial $^{1}$ & Control $^{1}$ & bST treated $^{2}$ \\
\hline \multirow[t]{2}{*}{ Manchega } & Nulli- or primiparous ${ }^{3}$ & 9 & 9 & 6 & 7 \\
\hline & Multiparous & 5 & 5 & 3 & 3 \\
\hline \multirow[t]{3}{*}{ Lacaune } & Nulli- or primiparous ${ }^{3}$ & 5 & 4 & - & - \\
\hline & Multiparous & 4 & 5 & - & - \\
\hline & Total & 23 & 23 & 9 & 10 \\
\hline
\end{tabular}

\footnotetext{
${ }^{1}$ Lactation was induced according to the standard protocol (Smith and Schanbacher, 1973) and milking started on d 21.

${ }^{2}$ Lactation was induced according to the standard protocol, bST (Lactotropina, $250 \mathrm{mg} / \mathrm{ewe}$; Elanco Animal Health Mexico, Guadalajara, Jalisco, México) was injected on d 11, and milking started on d 21.

${ }^{3}$ Nulliparous ewes induced into lactation and primiparous ewes of natural lactation.
}

bST syringe was measured and carefully marked to use one half for each ewe $(250 \mathrm{mg} / \mathrm{ewe})$.

\section{Feeding and Management Conditions}

Ewes grazed for 6 h daily on an Italian ryegrass pasture and were fed indoors with dehydrated Italian ryegrass hay ad libitum (12\% CP; as fed) and $0.5 \mathrm{~kg}$ of alfalfa pellets (17\% CP; as fed). Ewes were milked twice daily (0800 and $1700 \mathrm{~h}$ ) in a double-12 stall parallel milking parlor (Westfalia-Separator Ibérica, Granollers, Spain) provided with individual feeders, headlocks, recording jars ( $2 \mathrm{~L} \pm 5 \%)$, and a low milk pipeline. A total of $0.6 \mathrm{~kg} / \mathrm{d}$ of commercial concentrate $\left(6.4 \mathrm{MJ}\right.$ of $\mathrm{NE}_{\mathrm{L}} / \mathrm{kg}$ and $16 \% \mathrm{CP}$; as fed) was distributed in 2 portions at the a.m. and p.m. milkings.

The milking machine was set at a vacuum pressure of $42 \mathrm{kPa}$, a pulsation rate of 120 pulses/min, and a pulsation ratio of $50 \%$. The milking routine included machine milking, stripping before cluster removal, and teat dipping in an iodine solution (P3-cide plus, Henkel Hygiene, Barcelona, Spain).

\section{Sample Collection, Analyses, and Measurements}

Milk yield in the lactation-induced ewes was recorded daily during the first week of lactation and thereafter weekly until wk 13 (experiment 1) or wk 5 (experiment 2) of lactation. No data were available for NAT ewes from wk 1 to 4 in experiment 1 because they were suckling their lambs. Consequently, the comparison between NAT and ART ewes in experiment 1 was based on data collected from wk 5 to 13 .

Milk composition was evaluated daily during wk 1 (experiment 1) and biweekly through wk 13 (experiment 1) and wk 5 (experiment 2). Milk samples of approximately $100 \mathrm{~mL}$ were collected individually and preserved with an antimicrobial tablet (Bronopol, Broad Spectrum Microtabs II, D\&F Control Systems, San Ramon, CA) at $4^{\circ} \mathrm{C}$ until analysis. Unhomogenized milk samples were analyzed with a near-infrared spectrometer (Foss NIRSystems 5000, Foss, Hillerød, Denmark) for content of $\mathrm{TS}$, fat, protein $(\mathrm{N} \times 6.38)$, true protein, and $\mathrm{CN}$ (Albanell et al., 1999). Whey protein was calculated by the difference between true protein and CN, and NPN was calculated by the difference between protein and true protein.

\section{Statistical Analyses}

Data were analyzed by the MIXED procedure for repeated measurements of SAS (SAS 9.1; SAS Inst. Inc., Cary, NC). The statistical mixed model contained the random effect of the animal within the treatment (NAT vs. ART in experiment 1 ; control vs. bST in experiment 2 ); the fixed effects of treatment, parity, and week of lactation; the interaction between treatment and week of lactation, and between treatment and parity; and the residual error. For experiment 2, a group effect (ewes previously induced in experiment 1 vs. ewes induced for the first time in experiment 2) was added to the model. Differences were detected by the PDIF test and significance was declared at $P<0.05$ unless otherwise indicated.

\section{RESULTS AND DISCUSSION}

Doses of estradiol and progesterone used in the present study were comparable to dosages previously used in ewes (Head et al., 1980; Kann, 1997) and goats (Chilliard et al., 1986; Salama et al., 2007), but were 5 times greater than those used in dairy cows (Smith and Schanbacher, 1973; Collier et al., 1977). However, the ratio between estradiol-17 $\beta$ and progesterone (1:2.5) used in our study was the same as that used in goats and cows.

As a consequence of the high level of estrogens used, ewes showed signs of prolonged estrus behavior during the 2 wk after the induction treatment while udders began to fill with mammary secretions. Similar behavior has been observed in cows (Smith and Schanbacher, 1973) and goats (Salama et al., 2007). 


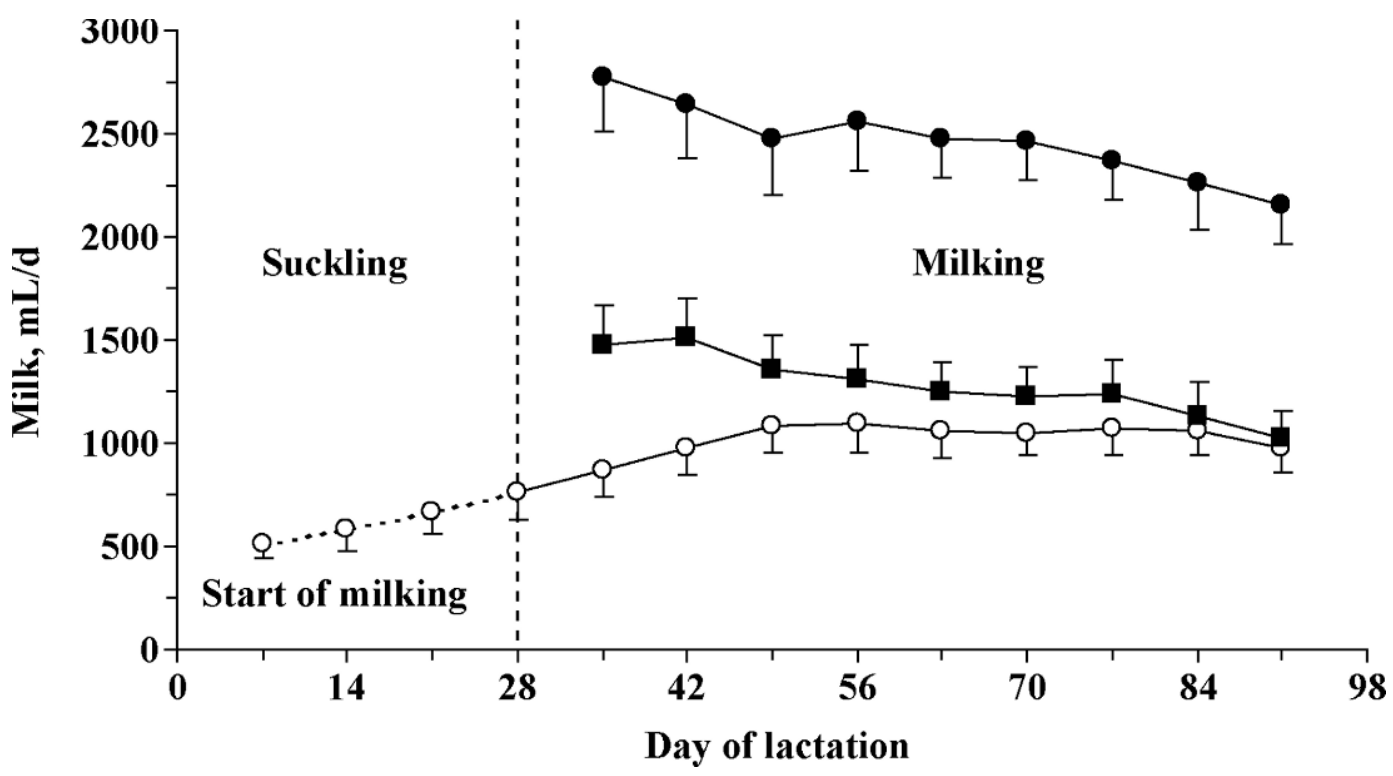

Figure 1. Milk yield in Lacaune $(\mathbf{O}, \mathrm{n}=9)$ and Manchega $(\mathbf{\square}, \mathrm{n}=14)$ dairy ewes milked after the weaning of their lambs and in Lacaune $(\mathrm{O}, \mathrm{n}=9)$ dairy ewes artificially induced to lactate (experiment 1$)$.

\section{Experiment 1}

Milk Yield. Response to the lactation induction treatment during winter differed between Manchega and Lacaune ewes. Most Manchega ewes (79\%) failed to be induced into lactation (of 14 ewes, only 2 nulliparous and 1 multiparous ewe produced more than $200 \mathrm{~mL} / \mathrm{d}$ in wk 2 of milking) with the standard protocol used, whereas all Lacaune ewes were successfully induced to lactate (all ewes produced more than $400 \mathrm{~mL} / \mathrm{d}$ at wk 2). A daily milk yield of $200 \mathrm{~mL}$ was taken as a criterion for lactation induction success according to the International Committee for Animal Recording (2005) minimum standard quantity of milk for milk recording in dairy sheep. To our knowledge, this is the first study showing a marked difference in the response to lactation induction based on genetic differences.

Lacaune dairy ewes yield more milk than Manchega ewes under the same management conditions (Molina et al., 2001; Marie et al., 2002), which implies that a different physiological milieu exists in each breed. Cows of high genetic merit produced more milk and had greater concentrations of plasma growth hormone than cows of low genetic merit (Kazmer et al., 1986; Westwood et al., 2000). Previous studies in Prealpes du Sud ewes, a low-milk-yielding breed, showed that the inclusion of growth hormone in the induction protocol improved the success rate and milk yield (Kann et al., 1999). Fernández et al. (1995) showed a 34 to $53 \%$ increase in milk yield of Manchega dairy ewes treated with bST, in the range of 80 to $240 \mathrm{mg} /$ ewe during lactation. Hormone levels, hormone receptors, transcription factors, or other factors that are involved in seasonal productive processes in the Lacaune ewes might have allowed them to respond better to the induction treatment; consequently the need for growth hormone in the induction protocol might be greater in Manchega than in Lacaune ewes. We cannot rule out the possibility that if Lacaune ewes had been treated with bST during the induction treatment, they would have yielded more milk.

In this experiment, ART Manchega ewes were dried off and a lactational performance comparison between NAT and ART was possible only for Lacaune ewes (Figure 1). At all weeks, differences in milk yield between NAT and ART Lacaune ewes were significant $(P<0.001)$ and, on average (wk 5 to 13), ART ewes yielded $49 \%$ the quantity of milk produced by NAT ewes $(1.23 \pm 0.14 \mathrm{vs}$. $2.51 \pm 0.15 \mathrm{~L} / \mathrm{d} ; P<0.001)$. This percentage fell within the range of 25 to $50 \%$ reported by Head et al. (1980) in Prealpes du Sud ewes and showed that lactation induction was only partly satisfactory.

Milk yield decreased $(P<0.001)$ in NAT ewes from the first milk recording after weaning of the lambs at wk $5(2.82 \pm 0.16 \mathrm{~L} / \mathrm{d})$ to $2.20 \pm 0.16 \mathrm{~L} / \mathrm{d}$ at wk 13 of lactation, showing an 89\% per month coefficient of persistency. In ART ewes, milk yield increased gradually from wk $1(0.51 \pm 0.15 \mathrm{~L} / \mathrm{d})$, peaked at wk $8(1.10 \pm 0.16$ $\mathrm{L} / \mathrm{d})$, and then slightly decreased to wk $13(0.97 \pm 0.15$ $\mathrm{L} / \mathrm{d} ; P=0.310$ ) of induced lactation. Monthly persistency coefficient from the peak was $91 \%$. Similar to our work, peak milk yield during induced lactation was at wk 9 to 11 in dairy cows (Collier et al., 1975), wk 7 in ewes (Head 
et al., 1980), and wk 9 to 10 in dairy goats (Salama et al., 2007). The delayed peak in ART ewes could be an indicator of continued mammary proliferation (Fowler et al., 1991) and differentiation (Chilliard et al., 1986; Fleming et al., 1986) during the first 2 mo after the start of lactation.

There were no differences in milk yield between nulliparous $(1.04 \pm 0.19 \mathrm{~L} / \mathrm{d})$ and multiparous $(1.00 \pm 0.21 \mathrm{~L} /$ d) Lacaune ewes in the ART group. Nevertheless, multiparous NAT ewes produced more milk than primiparous NAT ewes $(2.95 \pm 0.21$ vs. $2.08 \pm 0.18 \mathrm{~L} / \mathrm{d} ; P<0.01)$. One may expect a greater response to induced lactation in multiparous than in nulliparous ewes, because multiparous ewes should have had more secretory cells exposed to the hormonal treatment. However, it seems that the induction treatment resulted in the activation of a similar number of cells regardless of parity number in ART ewes. On the other hand, consecutive pregnancies in multiparous animals resulted in a higher number of activated mammary secretory cells than in primiparous animals that lambed once.

Milk Composition. Milk composition on the first day of induced lactation (d 21) in ART Lacaune ewes averaged TS, $16.5 \%$; fat, $4.02 \%$; protein (data not shown), $8.52 \%$; CN, 3.85\%; whey protein, $4.66 \%$; and NPN, $0.48 \%$. Milk composition changed dramatically during the first week of lactation in ART ewes, as shown in Figure 2.

Compared with colostrum, whey protein, most of which is Ig, was low in the first-day secretion and represented only $55 \%$ of total milk protein (data not shown). Caja et al. (2006) reported that whey proteins account for $72 \%$ of total protein in the normal colostrum of goats. Consequently, the first secretion obtained on $\mathrm{d} 21$ from the induced Lacaune ewes did not fully mimic normal colostrum. Smith et al. (1971) obtained a fluid nearly identical to colostrum on 17 of treatment in cows. The low whey protein content, and thus an implied low Ig content, of the first secretion in our results might have been a consequence of the corticoid treatment. Winger et al. (1995) showed that IgG concentration in cow milk peaked on $\mathrm{d} 15$ of the lactation induction treatment and then decreased gradually, and that injection with dexamethasone triggered sharp decreases in IgG concentrations in mammary secretions. The decrease in IgG concentrations after dexamethasone injection might have been due to decreased IgG transfer into the mammary gland, dilution by increased milk secretion, or a combination of these 2 factors (Winger et al., 1995). First milking was done in our case on d 21, and dexamethasone had been injected daily from d 18 to 20 , which may explain why this secretion differed from normal colostrum.

Milk protein and CN percentages in ART Lacaune ewes were high during the first $2 \mathrm{~d}$ of lactation, decreased
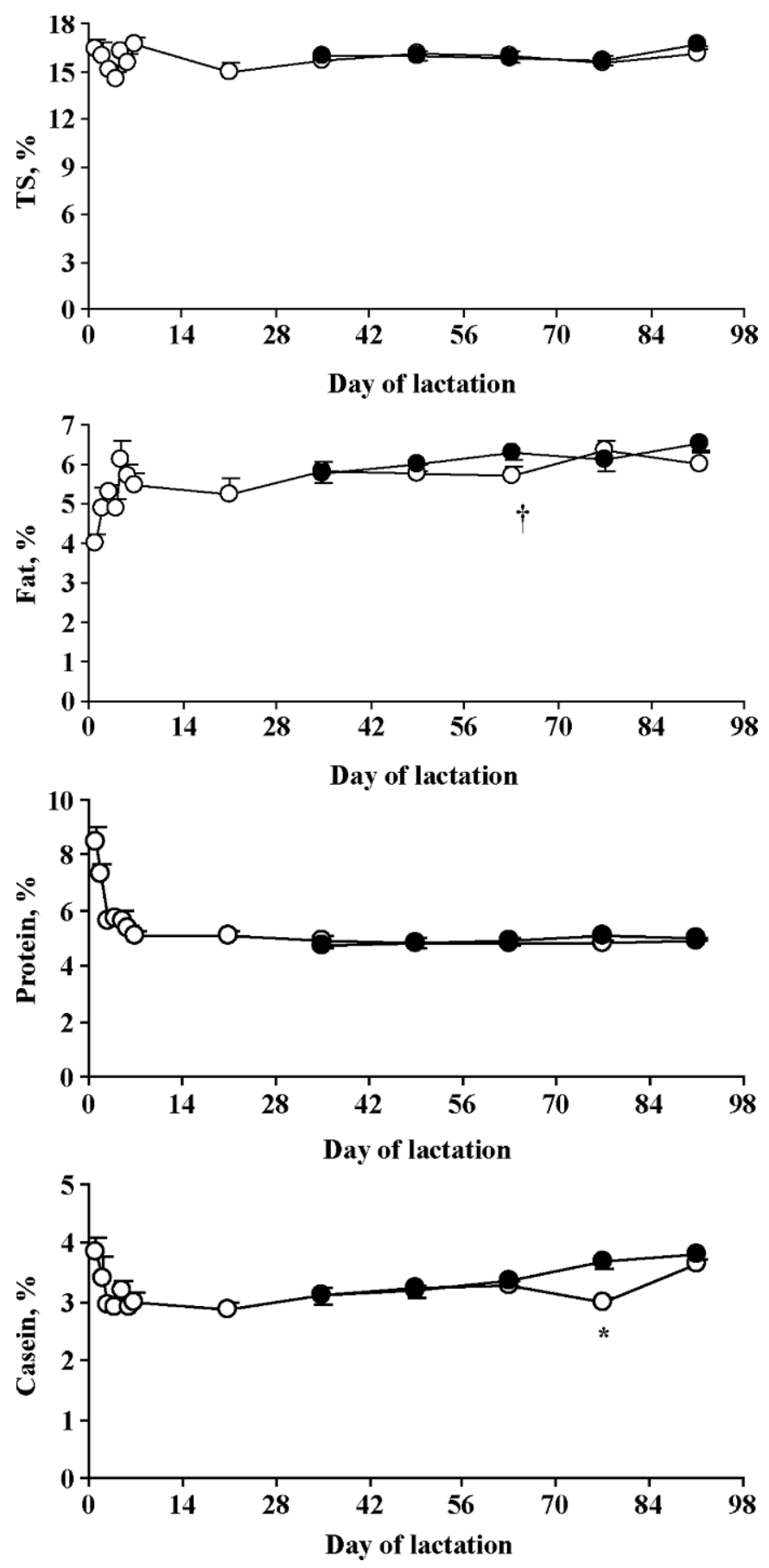

Figure 2. Milk composition in Lacaune dairy ewes naturally ( $\mathrm{n}=9$ ) or artificially $(\bigcirc, \mathrm{n}=9)$ induced to lactate (experiment 1$)$. An asterisk $(*)$ and a dagger $(\dagger)$ indicate a difference between naturally and artificially induced ewes at $P<0.05$ and $P<0.10$, respectively.

by d $3(P<0.05)$ to standard milk values, and remained constant thereafter (Figure 2). Similar changes were reported in induced nulliparous dairy goats (Salama et al., 2007). On the other hand, milk fat and TS values 
Table 2. Least squares means of average milk composition from wk 5 to 13 in Lacaune dairy ewes naturally or artificially induced to lactate (experiment 1)

\begin{tabular}{lcccc}
\hline & \multicolumn{2}{c}{ Lactation } & & \\
\cline { 2 - 3 } & $\begin{array}{c}\text { Natural } \\
\text { Milk component, \% }\end{array}$ & $\begin{array}{c}\text { Induced } \\
(\mathrm{n}=9)\end{array}$ & & \\
\hline TS & 15.99 & 15.87 & 0.30 & 0.684 \\
Fat & 6.14 & 5.92 & 0.23 & 0.360 \\
Protein & 4.89 & 4.88 & 0.13 & 0.915 \\
CN & 3.44 & 3.25 & 0.11 & 0.112 \\
CN, \% of protein & 69.9 & 66.6 & 1.33 & 0.029 \\
Whey proteins & 1.25 & 1.47 & 0.08 & 0.018 \\
NPN & 0.20 & 0.17 & 0.04 & 0.357 \\
\hline
\end{tabular}

${ }^{1}$ Standard error of the difference.

stabilized later than milk protein and $\mathrm{CN}$, and from $\mathrm{d}$ 7 onward these values were constant (Figure 2).

Despite the large and significant difference between NAT and ART Lacaune ewes in milk yield, there were no differences in milk composition from wk 5 to 13 (Table 2 and Figure 2), except that whey protein was greater in ART than in NAT ewes. Similarly, the composition of milk from induced lactation was not different from milk from lactations that followed parturition in dairy cows (Narendran et al., 1974) and dairy goats (Chilliard et al., 1986). The lack of differences between groups in the main milk components suggested that the induction treatment resulted in less mammary cell hyperplasia than did pregnancy-initiated lactation; however, the biosynthetic capacity of the cells was similar.

Values for the $\mathrm{CN}$ :protein ratio in both groups were lower than expected for standard ewe milk (74 to 77\%; Molina et al., 2001; Marie et al., 2002) and were greater $(P<0.05)$ in NAT than in ART ewes (Table 2). Salama et al. (2007) also reported that milk of goats induced to lactate contained a lower $\mathrm{CN}$ :protein ratio than milk of normally lactating goats. The low $\mathrm{CN}$ :protein ratio in NAT ewes may be a consequence of the negative energy balance observed during early lactation in Lacaune ewes under similar feeding conditions (Molina et al., 2001; Marie et al., 2002).

\section{Experiment 2}

Milk Yield. The Manchega ewes that responded poorly to the standard protocol in experiment 1 during winter (success rate, 21\%) responded much better in experiment 2 , which was conducted during spring. Milk yields in the first $2 \mathrm{wk}$ of lactation were greater than $200 \mathrm{~mL} / \mathrm{d}$ for 14 of 19 ewes (success rate, 74\%). The success rate of lactation induction did not differ $(P=$ $0.510)$ between control $(67 \%, 6$ of 9 ewes) and bSTtreated ( $80 \%, 8$ of 10 ewes) ewes, or between nulli- and multiparous ewes, although the nulliparous ewes had a higher numerical success rate (69 vs. $33 \%$, respectively; $P=0.111$ ). This result might indicate a different response to the same hormone dose, depending on parity of the ewe. Bridges and Byrnes (2006) reported that previous reproductive experience reduces circulating $17 \beta$-estradiol and prolactin levels in rats, and affects the estrogen-mediated processes beyond first lactation. Nulliparous rats were more sensitive than multiparous rats to lower doses of estradiol benzoate, whereas multiparous rats were more responsive to the higher doses.

The increased success rate of lactation induction in experiment 2 might be a consequence of an improvement in the hormonal milieu in Manchega dairy ewes during spring. Lactation induction for experiment 2 was conducted in April, under increasing photoperiod conditions after the spring equinox, whereas the induction in experiment 1 was in January, close to the winter solstice. Kensinger et al. (1979) showed that dairy cows induced into lactation in spring had greater basal levels of prolactin and milk yields than those induced in winter. Moreover, Kann (1997) reported that ewes exposed to a longday photoperiod had greater plasma concentrations of prolactin, growth hormone, and IGF-I, which may result in a hormonal milieu during spring that promotes greater mammogenesis and lactogenesis. The importance of prolactin for mammogenesis was shown by Salama et al. (2007), who reported that goats treated with reserpine (used as a prolactin releaser around the spring equinox) produced $28 \%$ more milk yield than goats induced to lactate without reserpine.

Despite the improved success rate, response to lactation induction in Manchega ewes during spring was still considered unsatisfactory. When the criterion for lactation induction success was increased to milk yield $>500$ $\mathrm{mL} / \mathrm{d}$, success rates were 11 and $60 \%$ in control and bSTtreated ewes, respectively $(P<0.05)$.

Milk yield after lactation induction was $98 \%$ greater in bST-treated ewes than in control ewes (402 \pm 85 vs. $203 \pm 86 \mathrm{~mL} / \mathrm{d} ; P=0.096$; Figure 3 ). The difference between groups might have been greater if ewes had been induced under short-day photoperiod conditions. Kann (1997) reported that milk yield enhancements caused by the use of human growth hormone-releasing factor in a lactation induction protocol in ewes were 31 and 148\% during long- and short-day photoperiods, respectively. The obtained results suggest an important role for prolactin and bST in the response to lactation induction in dairy sheep.

Peak milk yield values of artificially induced Manchega ewes in experiment 2 occurred earlier (wk 2; Figure 3) than in experiment 1 (wk 8; Figure 1) or than reported in the literature (wk 8 to 11). Peak milk yield values for control and bST-treated ewes (Figure 3) were only 21 and $32 \%$ of the peak values observed in contem- 


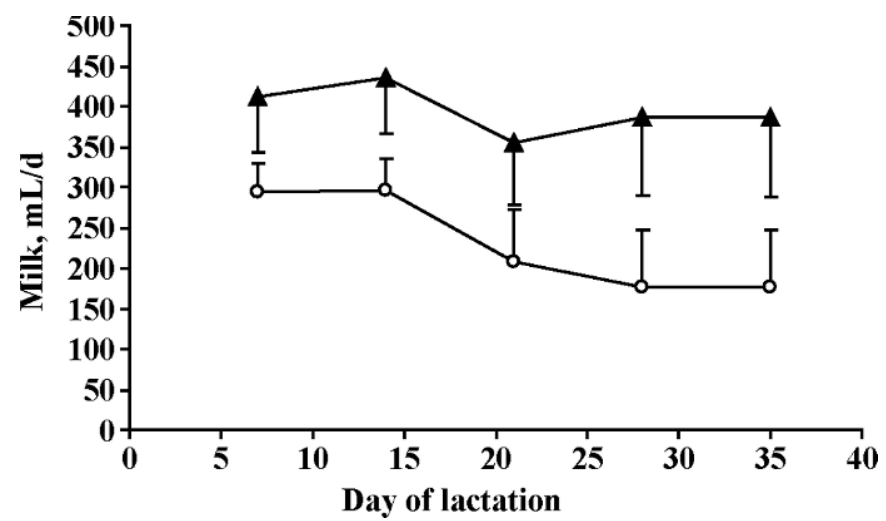

Figure 3. Milk yield of Manchega dairy ewes induced to lactate with $(\boldsymbol{\Lambda}, \mathrm{n}=10)$ or without $(O, \mathrm{n}=9) \mathrm{bST}$ (experiment 2$)$.

porary Manchega ewes lactating naturally after lambing in the same herd (Figure 1). This may be the result of an interrupted or incomplete proliferation or differentiation of the secretory mammary epithelial cells in lactation-induced ewes. The milk yield decrease in control ewes after wk 2 (Figure 3) was unexpected. The use of bST after the start of lactation induction, as reported by Magliaro et al. (2004) in cows, might be a solution to maintain and increase milk yield in Manchega ewes induced to lactate. The milk yield and milk composition response of Manchega dairy ewes to bST doses was evaluated by Fernández et al. (1995).

Milk Composition. Despite the differences in milk yield discussed previously, milk composition of Manchega ewes induced to lactate was similar in control and bST-treated ewes throughout the experimental period (Table 3). When bST was injected during an established lactation in dairy ewes, milk yield increased, but milk composition was not affected (D'Urso et al., 1998). However, the treatment of Manchega dairy ewes with bST during early and midlactation reduced milk protein in both stages, whereas milk fat increased during early

Table 3. Least squares means of average milk composition from wk 1 to wk 5 in Manchega dairy ewes induced to lactate with or without bST (experiment 2)

\begin{tabular}{lcccr}
\hline & \multicolumn{2}{c}{ Induced lactation } & & \\
\cline { 2 - 3 } Milk component, \% & $\begin{array}{c}\text { Control } \\
(\mathrm{n}=9)\end{array}$ & $\begin{array}{c}\text { bST treated } \\
(\mathrm{n}=10)\end{array}$ & SED $^{1}$ & $P$-value \\
\hline TS & 18.14 & 17.49 & 0.70 & 0.377 \\
Fat & 7.69 & 7.36 & 0.59 & 0.952 \\
Protein & 6.20 & 5.98 & 0.34 & 0.536 \\
CN & 4.64 & 4.49 & 0.21 & 0.493 \\
CN, \% of protein & 75.0 & 75.3 & 1.93 & 0.882 \\
Whey proteins & 1.18 & 1.07 & 0.16 & 0.494 \\
NPN & 0.38 & 0.43 & 0.03 & 0.149 \\
\hline
\end{tabular}

${ }^{1}$ Standard error of the difference. lactation but was not affected during late lactation (Fernandez et al., 1995). Values of milk composition fell within the range reported for normal milk composition after lambing in Manchega dairy ewes (Casals et al., 1999; Molina et al., 2001).

\section{CONCLUSIONS}

Significant differences between Manchega and Lacaune dairy ewes were observed in the response to lactation induction when using the standard protocol of Smith and Schanbacher (1973) during winter, in that Manchega ewes were unable to establish lactation. Nevertheless, milk yield in Lacaune ewes induced to lactate was only one-half that of the lambed contemporary ewes. The main milk components did not vary between induced and natural lactation, although whey protein content and the $\mathrm{CN}$ :protein ratio were impaired by lactation induction. Manchega ewes had an improved response to the standard protocol of lactation induction during spring. Milk yield was improved by the use of bST during induction (premilking), thereby suggesting a mammogenic and lactogenic effect in sheep, although the milk yield attained was unsatisfactory. The use of bST during mammogenesis did not affect milk composition. It seems that the response to lactation induction in dairy ewes was related to prolactin and growth hormone levels, the use of which should be explored more deeply in future research.

\section{ACKNOWLEDGMENTS}

This work is part of a CICYT Research Project (AGL 2002-03472) funded by the Spanish Ministry of Science and Technology. The authors are grateful to Ramón Costa and the team of the S1GCE of the UAB for care of the animals and to Nic Aldam for reviewing the manuscript.

\section{REFERENCES}

Albanell, E., P. Cáceres, G. Caja, E. Molina, and A. Gargouri. 1999. Determination of fat, protein, and total solids in ovine milk by near-infrared spectroscopy. J. AOAC Int. 82:753-758.

Alifakiotis, T. A., I. Katanos, I. Hatjiminaoglou, N. Zervas, and G. Zerfiridis. 1980. Induced lactation in dairy ewes by various brief hormone treatments. J. Dairy Sci. 63:750-755.

Bridges, R. S., and E. M. Byrnes. 2006. Reproductive experience reduces circulating $17 \beta$-estradiol and prolactin levels during proestrus and alters estrogen sensitivity in female rats. Endocrinology 147:2575-2582.

Byatt, J. C., R. H. Sorbet, P. J. Eppard, T. L. Curran, D. F. Curran, and R. J. Collier. 1997. The effect of recombinant bovine placental lactogen on induced lactation in dairy heifers. J. Dairy Sci. 80:496-503.

Caja, G., A. A. K. Salama, and X. Such. 2006. Omitting the dry-off period negatively affects colostrum and milk yield in dairy goats. J. Dairy Sci. 89:4220-4228. 
Casals, R., G. Caja, X. Such, C. Torre, and S. Calsamiglia. 1999. Effects of calcium soaps and rumen undegradable protein on the milk production and composition of dairy ewes. J. Dairy Res. 66:177191.

Chilliard, Y., C. Delouis, M. C. Smith, D. Sauvant, and P. MorandFehr. 1986. Mammary metabolism in the goat during normal or hormonally-induced lactation. Reprod. Nutr. Dev. 26:607-615.

Collier, R. J., D. E. Bauman, and R. L. Hays. 1975. Milk production and reproductive performance of cows hormonally induced into lactation. J. Dairy Sci. 58:1524-1527.

Collier, R. J., D. E. Bauman, and R. L. Hays. 1977. Effect of reserpine on milk production and serum prolactin of cows hormonally induced into lactation. J. Dairy Sci. 60:896-901.

Cowie, A. T., C. P. Cox, S. J. Folley, Z. D. Hosking, M. Naito, and J. S. Tindal. 1965. The effects of the duration of treatments with estrogen and progesterone on the hormonal induction of mammary growth and lactation in the goat. J. Endocrinol. 32:129-139.

D’Urso, G., M. Avondo, S. Bordonaro, D. Marletta, and A. M. Guastella. 1998. Effect of sustained-release somatotropin on performance and grazing behavior of ewes housed at different stocking rates. J. Dairy Sci. 81:958-965.

Fernández, N., C. Rodriguez, M. Peris, M. Barcelo, M. P. Molina, and A. Torres. 1995. Bovine somatotropin dose titration in lactating dairy ewes. 1. Milk yield and milk composition. J. Dairy Sci. 78:1073-1082.

Fleming, J. R., H. H. Head, K. C. Bachman, H. N. Becker, and C. J. Wilcox. 1986. Induction of lactation: Histological and biochemical development of mammary tissue and milk yields of cows injected with estradiol- $17 \beta$ and progesterone for 21 days. J. Dairy Sci. 69:3008-3021.

Fowler, P. A., C. H. Knight, and M. A. Foster. 1991. In-vivo magnetic resonance imaging studies of mammogenesis in non-pregnant goats treated with exogenous steroids. J. Dairy Res. 58:151-157.

Hart, I. C., and S. V. Morant. 1980. Roles of prolactin, growth hormone, insulin and thyroxine in steroid-induced lactation in goats. J. Endocrinol. 84:343-351.

Head, H. H., C. Delouis, M. Terqui, G. Kann, and J. Djiane. 1980. Effects of various hormone treatments on induction of lactation in the ewe. J. Anim. Sci. 50:706-712.

International Committee for Animal Recording. 2005. International agreement of recording practices. Guidelines approved by the General Assembly held in Sousse, Tunisia, June 2004. Int. Committee Anim. Recording, Rome, Italy.

Kann, G. 1997. Evidence for a mammogenic role of growth hormone in ewes: Effects of growth hormone-releasing factor during artificial induction of lactation. J. Anim. Sci. 75:2541-2549.

Kann, G., A. Delobelle-Deroide, L. Belait, A. Gertler, and J. Djiane. 1999. Demonstration of in vivo mammogenic and lactogenic effects of recombinant ovine placental lactogen and mammogenic effect of recombinant ovine GH in ewes during artificial induction of lactation. J. Endocrinol. 160:365-377.

Kazmer, G. W., M. A. Barnes, R. M. Akers, and R. E. Pearson. 1986. Effect of genetic selection for milk yield and increased milking frequency on plasma growth hormone and prolactin concentration in Holstein cows. J. Anim. Sci. 63:1220-1227.

Kensinger, R. S., D. E. Bauman, and R. J. Collier. 1979. Season and treatment effects on serum prolactin and milk yield during induced lactation. J. Dairy Sci. 62:1880-1888.

Kensinger, R. S., A. L. Magliaro, A. C. W. Kauf, M. L. O'Connor, and L. D. Muller. 2006. Effect of bST administration during induction of lactation in 15-month-old heifers on production and health. J. Dairy Sci. 89(Suppl. 1):333. (Abstr.)

Lukas, J. M., W. J. Weber, R. J. Collier, J. L. Vicini, M. F. McGrath, and B. A. Crooker. 2003. Imtramammary infusion of prostaglandin $\mathrm{E}_{2}$ (PGE) increases mammary development and milk yield of cows induced to lactate. J. Dairy Sci. 86(Suppl. 1):189. (Abstr.)

Magliaro, A. L., R. S. Kensinger, S. A. Ford, M. L. O'Connor, L. D. Muller, and R. Graboski. 2004. Induced lactation in nonpregnant cows: Profitability and response to bovine somatotropin. J. Dairy Sci. 87:3290-3297.

Marie, C., X. Such, F. Barillet, F. Bocquier, and G. Caja. 2002. Efficacité alimentaire selon le potentiel laitier des brebis. Options Méditerranéennes Serie B 43:57-71.

Molina, E., A. Ferret, G. Caja, S. Calsamiglia, X. Such, and J. Gasa. 2001. Comparison of voluntary food intake, apparent digestibility, digesta kinetics and digestive tract content in Manchega and Lacaune dairy sheep in late pregnancy and early and mid lactation. Anim. Sci. 72:209-221.

Narendran, R., R. R. Hacker, T. R. Batra, and E. B. Burnside. 1974. Hormonal induction of lactation in the bovine: Mammary gland histology and milk composition. J. Dairy Sci. 57:1334-1340.

Salama, A. A. K., G. Caja, E. Albanell, S. Carne, R. Casals, and X. Such. 2007. Mammogenesis and induced lactation with or without reserpine in nulliparous dairy goats. J. Dairy Sci. 90:3751-3757.

Smith, K. L., L. A. Muir, L. C. Ferguson, and H. R. Conrad. 1971. Selective transport of IgG-I into the mammary gland: Role of estrogen and progesterone. J. Dairy Sci. 54:1886-1894.

Smith, K. L., and F. L. Schanbacher. 1973. Hormone induced lactation in the bovine. I. Lactational performance following injections of $17 \beta$ estradiol and progesterone. J. Dairy Sci. 56:738-743.

Westwood, C. T., I. J. Lean, J. K. Garvin, and P. C. Wynn. 2000. Effects of genetic merit and varying dietary protein degradability on lactating dairy cows. J. Dairy Sci. 83:2926-2940.

Winger, K., C. C. Gay, and T. E. Besser. 1995. Immunoglobulin G1 transfer into induced mammary secretions: The effect of dexamethasone. J. Dairy Sci. 78:1306-1309. 